\title{
Evaluation Of The Decentralization Experience In Jordan By Local Stakeholders
}

https://doi.org/10.21272/sec.5(4).55-73.2021

Prof. Dr. Aljaloudi, Jameel, ORCID ID: https://orcid.org/0000-0002-2924-4119

Department of Planning and Project Management, College of Business, Al-Balqa Applied University, Jordan

Prof. Dr. Abu Zaid, Mohammad, ORCID ID: https://orcid.org/0000-0002-6320-9878

Department of Planning and Project Management, College of Business, Al-Balqa Applied University, Jordan

Mr. Alfauri, Moath, ORCID ID: https://orcid.org/0000-0003-0021-8264

Arab medical Center, Amman, Jordan

\begin{abstract}
The study aims to evaluate Jordan's experience in decentralization at the regional and local levels by heads and members of provincial councils, municipal councils and opinion leaders. This evaluation includes the three dimensions of decentralization (political, financial and administrative). For evaluation purposes, two questionnaires were designed. The first one for the governorates and the second one for the municipalities. The questionnaires were judged by academic experts and verified for credibility. The sample size was (578) and distributed as follows (141) at the governorate level, (370) at the municipality level, and the rest belong to opinion leaders in the communities. The statistical program SPSS was used to enter and analyze the data. The descriptive statistical method was used, represented by the arithmetic mean and standard deviation. The t-test was used to test the validity of the null hypotheses at a level of significance (0.05). The finding indicates that there is a moderate extent of the implementation of political, fiscal, and decentralization in Jordan at regional with a mean variable (3.13), (2.70), and (3.10), and with the estimated standard division was (1.10), (1.08), and (0.98) respectively. It indicates also a moderate extent of decentralization in all dimensions (political, fiscal, and administrative) at Municipality level with a mean variable (2.62), (2.98), and (2.84), and with the estimated standard division was (1.20), (1.026), and (1.037) respectively . The statistical tests for all the main and subhypotheses confirmed the acceptance of the null hypothesis, which means that the degree of decentralization in all its three dimensions (political, financial and administrative) is low in Jordan. The study recommended that decision-makers should review the experience and amend the laws governing decentralization in order to ensure more decentralization in its political, financial and administrative dimension.
\end{abstract}

Keywords: state and local government, public administration, decentralization in Jordan.

JEL Classification: H77, H83, H79.

Cite as: Aljaloudi, Jameel, Abu Zaid, Mohammad, Alfauri, Moath (2021). Evaluation Of The Decentralization Experience In Jordan By Local Stakeholders. SocioEconomic Challenges, 5(4), 55-73. https://doi.org/10.21272/sec.5(4).55-73.2021.

Received: $04.10 .2021 \quad$ Accepted: 30.11.2021 Published: 30.12 .2021

Copyright: (C) 2021 by the authors. Licensee Sumy State University, Ukraine. This article is an open access article distributed under the terms and conditions of the Creative Commons Attribution (CC BY) license (https://creativecommons.org/licenses/by/4.0/). 


\section{Introduction}

Jordan is a unified state based on a high degree of political, administrative and financial centralization with a two-tiered system of subnational government (the 12 governorates, and the 100 municipalities). Each governorate is headed by a governor appointed by the king through the Ministry of Interior, who works alongside the decentralized directorates of the executive ministries as an extension of the central government. They are administrative units directly linked to the Ministry of Interior. As for the municipalities, they enjoy some financial and administrative independence (Municipality Law, 2015). It is subject to the supervision of the Ministry of Municipal Affairs, except for the Greater Amman Municipality and the Aqaba Special Economic Zone.

The central level still provides all basic services to the citizen including water, electricity, gas, sewage, primary education, health care, among others. As for the municipalities, they have traditionally played a marginal role in providing local services to the citizen due to the weakness of the political authority, the lack of qualified human and non-human resources, and the insufficiency of funding resources. As a result, a number of the municipal functions stipulated in the Municipal Law 2015 are performed by central government units rather than by municipalities.

The application of this central model led to the following:

$>$ The failure of successive governments to provide public services to citizens in an unfair manner (increasing regional disparity).

$>$ The inadequacy of development projects to the needs and desires of citizens in the governorates.

$>$ Weak popular participation in decision-making and contribution to regional and local development.

$>$ Increasing the regional variation in unemployment and poverty rates.

$>$ Increasing the public financial burden of the central government (such as an increase in the public budget deficit, an increase in public indebtedness and an increase in tax burden).

The issuance of the decentralization law in 2015 was the result of the following:

$>$ Royal directives in 2005 on the need for political and administrative reform.

$>$ Implementation of Jordan's vision - 2025 .

$>$ Assisting foreign donor countries in building an appropriate decentralization model and benefiting from their experiences in this field.

According to this law, an elected council was formed for each governorate and granted development, investment and oversight powers. Giving governors additional powers in the field of regional planning and development. It is believed that this decentralized model contributes to a better fight against unemployment and poverty. To ensure the quality of public services and their suitability to the needs of citizens. Stimulate the regional economy, and achieve regional development based on strong popular participation.

After the provincial elections were held in 2017, and these councils exercised their duties, the urgent need to amend the current model emerged after the royal meeting with the heads of the provincial councils and the royal directive of the central government to amend the Decentralization Law 2015 and the Municipal Law 2015. As a result, the central government reformed through the preparation of a draft local administration law. The draft of Local Administration Law has been prepared by the central government to replace the 2015 Decentralization Law and the current Municipalities Law 2015. It presented by central government to the legislative authority for discussion and approval in summer 2021. This urged without any participation of members of the elected councils and opinion leaders in the governorates to express their opinion on this draft law.

This study aims to evaluate the decentralization model in Jordan by the heads and members of the elected councils, and the opinion leaders in the governorates, by conducting a sample survey.

The study will answer the following main question:

To what extent do stakeholders evaluate the decentralization experience in Jordan? 
As well as the answer to the sub-questions related to the three dimensions of decentralization, namely:

1. To what extent do stakeholders evaluate the experience of political decentralization in Jordan?

2. To what extent do stakeholders evaluate the experience of administrative decentralization in Jordan?

3. To what extent do stakeholders evaluate the experience of financial decentralization in Jordan?

The importance of this study is that it deals with a very important issue in Jordanian society, and its findings and recommendations are believed to contribute to assisting Jordanian legislators and decision-makers when amending the 2015 decentralization law. Its importance from an academic point of view is that it helps researchers understand and develop the Jordanian experience .

This study consists of the introduction, the theoretical framework and previous studies in the second part, the methodology in the third part, the decentralized model according to the 2015 decentralization law in the fourth part, the analysis of the output and recommendations in the fifth part, and the conclusion and recommendation in sixth section.

\section{Theoretical Framework and Field Studies 1.1 Theoretical Framework}

(The World Bank, 2013) defines Decentralization as "transfers authority and responsibility of major government functions from central to sub-national governments - including local governments, civil society, and the private sector". The United Nations Development Program ( UNDP, 1997) defines decentralization also as following: Decentralization, or decentralizing governance, refers to the restructuring or reorganization of authority so that there is a system of co-responsibility between institutions of governance at the central, regional and local levels according to the principle of subsidiarity, thus increasing the overall quality and effectiveness of the system of governance, while increasing the authority and capacities of sub-national levels".

Decentralization could also be expected to contribute to key elements of good governance, such as increasing people's opportunities for participation in economic, social and political decisions; assisting in developing people's capacities; and enhancing government responsiveness, transparency and accountability.

For researchers in their scientific papers, decentralization usually means the transfer of powers from centralization government to lower levels in the political, administrative, and territorial hierarchy) Crook and Manor 1998, Agrawal and Ribot 1999). Some believe that the transfer of power takes two main forms: administrative decentralization and political or democratic decentralization (the transfer of power to representative actors and downward accountability, such as Elected Local Governments (Rebot, 2002).

Decentralization can take many forms, such as: Devolution, Delegation, Deconcentration, or Divestment/Privatization. Researchers postulate three basic dimensions to the concept of decentralization. They are: political decentralization, administrative decentralization and financial decentralization. Adopting of a decentralization model (Schneider, A., 2003) (financial, administrative and political) mostly leads to: improving efficiency (or economic benefits), improving political and financial accountability and improving effectiveness. At the same time, it is likely to lead to the following negative effects: macroeconomic instability, a decline in investment in social infrastructure, - an increase in inequality and horizontal conflicts, a breakdown of the safety net (poverty), and any increase in corruption in regional and local bodies. The sum of these effects depends on choosing a model of decentralization that is commensurate with the political, economic and social conditions in the state. Continuous work on evaluating and updating it in a way that maximizes the positives and avoids the negatives resulting from its application. The application of a decentralized model with its dimensions (political, administrative and financial) that ensures maximizing the positive effects and minimizing the negative effects requires verifying the availability of the following prerequisites:

1. Political Will: There must be a strong political will from all leaders at all levels in society that supports decentralization reform. 
2. Legal framework: Preparing an appropriate legal framework for decentralization, which clearly defines the tasks of each of the regional and local bodies and their financial sources. It also describes their rights and responsibilities to central authorities, local communities, courts and other important stakeholder.

3. Institutional structures: The organizational structures of official bodies (central, regional and local) must be aligned with their new functions. In addition to the need to carry out training and continuous technical support for the employees of these institutions to enable them to carry out their new responsibilities efficiently and effectively.

4. Ensuring the oversight of the central government and people's organizations: Finding mechanisms and systems that guarantee the oversight of the central government and others that guarantee the oversight of civil society institutions and private sector institutions. These would ensure that regional and local institutions provide subnational public services to citizens and investors in a satisfactory, effective and lowcost manner.

\subsection{Field Studies}

Al-Jaloudi (2021) measured the degree of fiscal decentralization in Jordan by estimating the indicators used by the World Bank and the International Monetary Fund. It is represented by the share of local units in public revenue and public spending share and share Compensation of workers in local units from the total Compensation for public sector workers. The study uses data on public revenue and central expenditures government and independent government units, as well as municipal budget numbers. These data covered the period 2016-2018 and were published electronically by the Ministry of Finance and the Ministry of Local Administration in Jordan. He found that the degree of financial decentralization is very low in Jordan, especially when compared to other countries that have implemented a decentralization reform. (Abu Jabal 2020) dealt with the study of the extent to which the administrative independence of the elected governorate councils in Jordan has been achieved, which was stipulated in the Decentralization Law 2015 on the one hand and in light of the method used in its formation on the other hand. He used the descriptive analytical approach, by reviewing the opinions of the jurists regarding administrative decentralization and its pillars and elements, and dropping the element related to the method of forming regional decentralized administrative units on the status of the governorate councils in Jordan, and then analyzing the legal texts related to this topic that were contained in the Jordanian legislation. With the possibility of presenting some comparative models of this idea with other legal systems, but within a specific scope. He concluded that these councils do not enjoy financial and administrative independence, as they remain under the influence of central government intervention through its authority to appoint (15\%) of its members. Accordingly, the researcher recommended the necessity of amending the law of decentralization to ensure the direct election of all council members. (Al-Sarhan, 2020) analyzed the results of the elections at the governorate level that were held in 2017, based on the decentralization law. He concluded that the percentage of participation in the elections was very low, estimated at (31.7\%), and to much lower in the predominantly urban governorates such as (Amman and Zarqa), where it was estimated (17.6\% and 20.1\%), respectively. The share of women was (13.9\%) of the total number of seats in those councils. The researcher concluded that the hypothesis of the study was not accepted: that the decentralization elections enhance the level of political participation in the management of local affairs. The decline in popular participation was attributed to the poor economic conditions suffered by the citizen and the lack of citizen confidence in the elected national parliaments in the past years. (Al-Tarwana, 2020), conducted a study on the participation of women in provincial and municipal councils, using the descriptive analytical method. It became clear to him that the participation of women in the regional and municipal elections that took place in 2017 was significant and important. The reason for this was attributed to the fact that the law included a certain share $(25 \%)$ in those councils. He recommended maintaining the percentage of women's representation in councils and the need for governments to continue educating communities in governorates and municipalities of the importance of the role of women in political participation. Taamneh.M et al. 2019 evaluated the decentralization experience in Jordan by providing an empirical test of the triple model of decentralization (political, administrative and financial) developed by Schneider (2003) and by using descriptive and inferential analyses. Sample survey was adopted. The sample size was (502) employees working in official departments at the governorate level, 
municipalities and civil society organizations in the northern governorates of Jordan (Irbid, Ajloun, Jerash and Mafraq).

The researchers found that the degree of decentralization in Jordan was estimated at a mean (3.12) and a standard deviation of 0.581 . As for each indicator, the average score was estimated at (3.33) for the political indicator, (3.11) for the financial indicator, and (2.95) for the administrative indicator. As a result, researchers believe that the local administration in Jordan still depends mainly on the local arms of the central authority. The researchers found that the degree of decentralization in Jordan was estimated at a mean (3.12) and a standard deviation of 0.581 . As for each indicator, the average score was estimated at (3.33) for the political indicator, (3.11) for the financial indicator, and (2.95) for the administrative indicator. As a result, researchers believe that the local administration in Jordan still depends mainly on the local arms of the central authority.

(Jordan Economic and Social Council 2019), worked on reviewing the governance and management system at the governorate level, which was prepared in accordance with the Decentralization Law No. 49 for the year 2105. It also evaluated its implementation in its first phase after the election of the governorate councils in 2017. This council called for the necessity of exerting efforts to formulate a vision and a coherent strategic policy on the decentralization process in Jordan. In light of this, it presented three possible options for structuring the governance and public administration system at the governorate level:

- The first option is to keep the system.

- The second option: establishing a local authority with full conditions at the governorate level.

- The third option: the establishment of a joint authority between the municipalities.

The Council recommended the necessity of preparing a national program for the implementation of decentralization under the umbrella of the Prime Ministry, in order to review the legislation governing decentralization, institutional development and capacity building at the local level.

(Al-Khawaldeh, S., 2019) dealt with identifying the nature of the constitutional and legal framework regulating the work of the provincial councils (their function and the method of electing and appointing its members). This study concluded that the constitutional and legal framework regulating the work of the governorate councils in Jordan is represented by the Jordanian Constitution of 1952 and its amendments, and the Decentralization Law No. 49 of 2015 AD. The governorate council is an elected council, (85\%) of its members are directly elected, provided that $10 \%$ is for women) and the rest (15\%) is appointed by the central government (5\%) of which is for females. In 2017, the provincial councils were elected for the first time. The study concluded that the governorate councils worked to expand the base of popular participation in local governance. The researcher recommended that all members of governorate councils should be elected directly by citizens, and that the powers and tasks of governorate councils should be increased.

Karak Castle Center for Consultation and Training in cooperation with Friedrich Ebert Office / Amman (2018), conducted a review of the decentralization law 2015. In this research, the focus group methodology was used, where 98 elected male members in 12 governorates participated in the discussions, and the main media interview methodology with all the heads of the 12 centers, and with 32 women out of 36 elected females in the governorate councils.

The results of this study indicated a negative evaluation of the decentralization experience, which can be explained as follows:

$>$ The biggest challenge facing the councils in the governorates is the law itself. Therefore, the councils did not achieve the expected goals and objectives of the decentralization system. Lack of sufficient powers to ensure control over the implementation of projects. Demanding the need to amend the decentralization law.

$>$ The government did not provide support to these councils with qualified administrative cadres. Ministries do not cooperate with them effectively. It did not provide financial sources to guarantee the financial independence of these councils. 
$>$ The necessity of training provincial council members to review and audit budgets, including gendersensitive budgets. They are also trained in effective methods for following up and monitoring the implementation process.

$>$ The necessity of training provincial council members to identify needs and prioritize the communities in which they work.

$>$ Other laws, such as the Municipal Law, and the laws relating to the work of executive councils, must be amended.

$>$ Many members of the Council lacked an understanding of their powers and the functions of the various official bodies.

$>$ Creating a new ministry to take over the responsibility of supervising the local administration in Jordan, to replace the Ministry of Municipal Affairs.

$>$ Increasing the share of women's participation in the membership of provincial councils.

(Abu Hazeem, 2016) has demonstrated the importance of implementing decentralization in the political reform process in Jordan from the viewpoint of the members of the seventeenth parliament. The descriptive survey method was adopted, and the study sample amounted to (51) members of the total number of members of the House of Representatives. The researcher concluded that there is a high degree of approval among the members of the seventeenth parliament on the importance of implementing decentralization in the political reform process in Jordan. He recommended the necessity of implementing decentralization, which guarantees the real . independence of the local councils, so that they can take their decisions and carry out their responsibilities easily.

Our review of previous field studies shows that most of them focused on the political dimension only, and some of them on the financial dimension only, to evaluate the decentralization experience in Jordan (except Taamneh study). Also, the target parties in these studies to know their views on the decentralization experience did not include all stakeholders involved in decentralization at the level of governorates and municipalities who represent the communities in these areas. Some of them were restricted to members of the House of Representatives and others to the women's sector or to the elected presidents and members of the provincial councils. Although the study of Tamannah included the three dimensions of decentralization, the study sample was limited to the interrogation of employees working in government departments in the governorates and municipalities in the northern region only. The study sample did not include the targeted members of the elected councils in the governorates and municipalities and opinion leaders in society and in all twelve governorates who represent citizens through direct election. The sample was limited to the northern governorates only and did not include the rest of the governorates in the center and south.

Therefore, this study complements the previous studies, and its originality lies in the fact that it includes the three dimensions of decentralization (political, administrative and financial) and that the study population in it are the heads and members of councils in the governorates and municipalities and opinion leaders in all twelve governorates and in all municipalities in Jordan. The sample will be selected from Al-Balqa Governorate and Amman Governorate (because of its political importance as the capital of Jordan, $42.0 \%$ of the total population, and $43.8 \%$ of total economic establishment), Irbid governorate is from the northern region, and Karak governorate is from the southern province.

\section{The Local Administrative System in Jordan}

The local administration system in Jordan consists of (12) governorates and (100) municipalities, including the Greater Amman Municipality, which has a special status as the capital of Jordan. It is directly linked to the central authorities (see Figure 1). In order to clarify the extent of decentralization in the Jordanian system of governance and administration, the parties involved in the local administration will be identified, the mechanism of its formation analyzed, and their tasks determined in order to provide public services to citizens, as follows: 


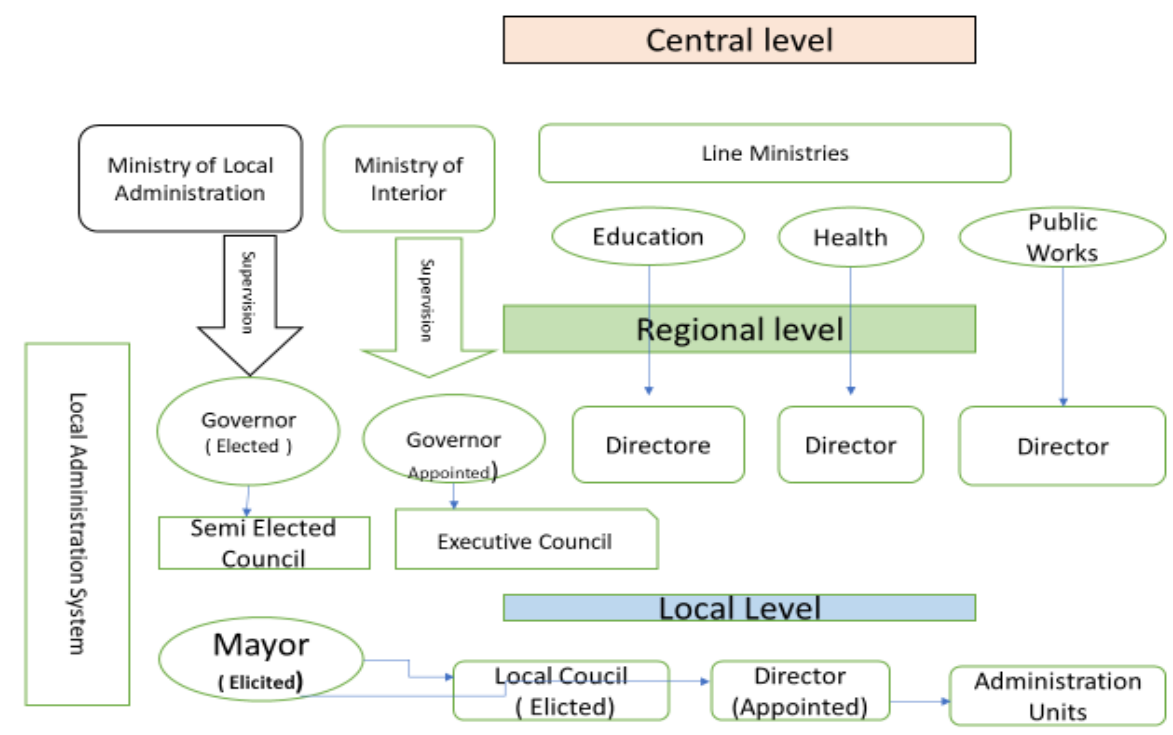

Figure 1. The Structure of Government in Jordan

Sources: prepared by the Authors.

\section{The Governorates}

\subsubsection{The Appointed Governor}

$\mathrm{He}$ is the public servant appointed by the king based on the recommendation of the Minister of Interior, who represents the king in the governorate. He chairs the Executive Council, of which the directors of the official departments of the various ministries are its members. According to Article 3 of the Decentralization Law 2015 the Governor shall undertake the following tasks:

1. Lead, supervise and ensure that the official bodies in the governorate are carrying out their tasks.

2. Follow up on the execution of state public policy in the governorate; take whatever necessary action needed to ensure these policies are heeded so that state departments and institutions in the governorate are performing their duties.

3. Coordinate among the council and municipalities of the governorate, the ministries, government departments and public institutions.

4. Supervise development and service plans and the preparation of the annual governorate budget.

5. Take the necessary measures to ensure the execution of the council's decisions; and refer these to the competent body.

6. Avail the best services to the citizens in coordination with the council.

7. Work with the council and the executive council to avail the appropriate environment to encourage investment at the governorate; avail socio-economic development requirements; and take the necessary measures to realize this in coordination with the stakeholders.

8. Protect state property, work on developing and utilizing it, and take necessary measures to guarantee this.

9. Take the necessary measures to protect health, public safety and the environment; formulate monitoring and inspection committees with the authority to temporarily close shops, enterprises and sites in violation; and seizing assets until these violations are referred to the competent court.

10. Take necessary measures in cases of emergency and coordinate efforts of all competent authorities.

11. Conduct periodic meetings for the council and committees that he/she presides over and take the measures necessary to execute their decisions and recommendations.

12. Exercise any powers or duties as delegated by the cabinet, the prime minister or the competent ministers. 


\subsubsection{The Executive Council}

\subsubsection{The Board membership}

An executive council is formed in each governorate (chaired by the Governor and with membership of:

1. The deputy governor, the administrators who preside over the districts, and two district administrators who they head the district directorates in the governorate and the assistant governor for development affairs.

2. Directors of the executive directorates and service departments in the governorate, and if there are more from the director of a directorate or department affiliated to a specific ministry named the competent minister or official

The first for the management of the sector is one of the directors of the directorates or departments, as the case may be, as a membervin the Executive Council.

3. Managers of development zones and industrial cities in the governorate, if any.

4. Three of the executive directors of municipalities in the governorate, a maximum, to be named by a minister of Municipal affairs.

5. One of the commissioners of the Aqaba Special Economic Zone Authority, to be named by its head in relation to Aqaba Governorate, and one of the commissioners of the Petra Development and Tourism Region Authority, named by its president, relates to Ma'an Governorate.

\subsubsection{The functions of the executive council}

The Executive Council shall assume the following duties and powers in a manner that does not conflict with the provisions of the law: Aqaba Special Economic Zone in force and the Petra Tourism Development Region Authority Law and the powers of the Board of Commissioners in each of them:

1. Preparing draft strategic and executive plans for the governorate and aligning them with the plans. The strategy prepared by the municipal councils and other official bodies, and to ensure that Its consistency with national strategies and plans and referring it to the Council for decision making appropriate about it.

2. Preparing a guide to the governorate's needs of development and service projects, including a guide The needs received from the municipalities and other official bodies and referred to the Council.

3. Preparing the governorate's budget draft within the ceilings specified by the Ministry of Finance / Department The general budget and referral to the Council.

4. Reviewing the general conditions in the governorate and discussing matters related to public services and to consider any proposal submitted by any member and take the necessary decisions in this regard. Review the reports it receives from the municipal councils, and take appropriate decisions in this regard.

5. Laying the foundations that ensure the proper functioning of the administrative and executive bodies in the governorate.

6. Submitting the necessary recommendations regarding investment in the governorate and referring them to the Council unless It conflicts with any other legislation.

7. Preparing reports on the progress of work in projects and services and referring them to the Board each six months.

8. Take the necessary measures regarding the decisions and recommendations issued by the Board.

9. Coordination with official and public bodies and institutions that have jurisdiction over plans and the programs it implements.

10. Study the issues referred to it by the governor or the council. 
11. Preparing the necessary emergency plans at the governorate level to face emergency cases Disasters such as floods, torrential rains, snow, fires and others, and submitting them to the Council.

\subsubsection{The elective Governor}

He is the member who is elected from among the members of the council (in its first meeting after the elections) as the president of this council

\subsubsection{The semi elective council}

\subsubsection{The Members}

Each governorate shall have a council called the governorate council, and it shall enjoy a legal personality with financial and administrative independence. $85 \%$ of the council members are directly elected (75\% for males and $10 \%$ for females) and the rest of the members (15\%) are appointed by the Council of Ministers upon the recommendation of the Minister of Interior provided that one third of this percentage is allocated to women. The term of the Council is four years. The Council of Ministers has the right to dissolve it upon the recommendation of the Minister of Interior before the end of the term of this Council

\subsubsection{The Responsibilities}

This Council shall undertake the following tasks ( in a manner that does not conflict with the provisions of the Aqaba Region Law, and the effective special economic law ):

1. Approving the projects of the strategic and executive plans related to the governorate and referred to it from the Executive Council and ensure its implementation.

2. Approval of the governorate's draft budget within the ceilings set by the Ministry of Finance, the general budget referred to by the Executive Council for inclusion in the general budget in accordance with Procedures for preparing the state's general budget.

3. See how to implement the annual budgets of all the governorate's municipalities.

4. Approval of a guide to the governorate's needs for development and service projects referred to it from Executive Board and prioritize those needs.

5. Approval of the service and investment projects referred to it by the Executive Council after Complete the necessary procedures in accordance with the applicable legislation.

6. Approval of development projects that are of public interest to the preservation taking into account the development projects proposed by municipal councils, departments and institutions official within the governorate and submit it to the governor to take the necessary measures in this regard.

7. Discussing the reports of the implementation of projects, plans and programs undertaken by the department's governmental authorities in the governorate to implement them in a manner that does not conflict with the work of government oversight bodies concerned with following up and evaluating the progress of development projects.

8. Suggesting the establishment of investment projects and carrying out joint projects with other governorates with the approval of the competent authorities.

9. Develop recommendations and proposals for the competent authorities to ensure the improvement of the performance of the departments Governmental and public institutions operating within the governorate to ensure the provision of the best services.

10. Determine the areas within the borders of the governorate that suffer from a lack of services and development or emergency problems and propose solutions to them from the relevant authorities and approve County contingency plan.

11. Discussion of any of the Executive Council members on the topics within his specialty. 
SocioEconomic Challenges, Volume 5, Issue 4, 2021

\section{2 \\ The Municipalities}

\subsubsection{The Mayer}

The mayor is a person who is directly elected by the citizens of the municipality. He is the head of the municipal council and exercises the following duties:

1. Inviting the Municipal Council to convene and presiding over its sessions

2. Representing the municipality in external meetings and conferences, subject to the approval of the Minister of Local Administration.

3. Preserving the rights of the municipality and defending its interests legally

4. Signing agreements, memoranda of understanding, protocols and twinning with the relevant authorities approved by the Municipal Council inside Jordan. If these agreements are with parties outside Jordan, the approval of the Minister of Local Administration is required.

5. Presenting the draft of (municipal budget, strategic plan, and local needs guide) to the municipal council for discussion and approval.

6. Presenting the various issues sent by the municipal executive director to the municipal council for discussion and approval.

\subsubsection{The Town council}

\subsubsection{The formation of the municipal council}

The municipality is a civil institution that enjoys a legal personality with financial and administrative independence. The municipality is managed by a council consisting of the president and a number of members (all of them were elected directly by the citizens of the municipality). The number of council members is determined by the Minister of Local Administration, and that the number of council members is not less than seven, including the president in any case.

An exception is made to the Greater Amman Municipality Council, whose members are determined by the Council of Ministers. It is composed as follows: (75\%) are the directly elected heads of the local councils of the Greater Amman Municipality, and (25\%) of the members are members appointed by the Council of Ministers and upon the recommendation of the Minister of Local Administration.

\subsubsection{Municipal council tasks}

The Municipal Council exercises the following powers:

1. Approval of the estimated annual draft budget as well as the actual budget

2. Approval of the local development strategic plan and a guide to the needs of the town

3. Follow up and monitor the implementation of development programs. Which can be implemented by the municipality itself or with the participation of other municipalities or with the private sector

4. $\quad$ Surveillance of open lands and protection of streets and roads

5. Coordination with the central official authorities in us regarding the determination of the locations of schools, health centers, and places of worship

6. Coordination with the central official authorities with regard to determining the distribution of electricity and water to citizens

7. Coordination with the central official authorities regarding the construction of sewage networks. And the establishment and operation of public toilets.

8.

Establishment and organization of public markets 
10. Construction of squares, gardens, parks and tourist places

11. Coordination with the Civil Defense Foundation to prevent and extinguish fires

12. Take the necessary measures to prevent natural disasters and establish public shelters

13. In coordination with the central official authorities, the establishment of museums, public libraries, sports and social clubs, and slaughterhouses

14. Construction, management and maintenance of cemeteries

15. Investing the movable and immovable property of the municipality

\subsubsection{Municipal Manager}

In each municipality, an executive director is appointed by a decision of the Minister of Local Administration and upon the recommendation of the municipal council. He is the head of the administrative body and is responsible for its proper functioning. He is responsible to the mayor and for preparing and implementing the annual budget for the municipality

\section{The Methodology}

The study community consists of opinion leaders and all members of the elected councils in all 12 governorates, and in all municipalities, a choice of (100). These categories were chosen because the researchers believe that these categories represent the concerned citizens and their satisfaction with the implementation of decentralization .

The study sample was determined to represent the entire study population, by selecting one governorate at random from each of the three regions. In addition to choosing the governorate of Amman due to its political, economic and demographic importance. It is the capital of Jordan and the seat of the central government, $42 \%$ of the total population resides in it, and $43.6 \%$ of the total economic establishments in Jordan reside there. Table No. 1 shows the sample size, which numbered 578, and their distribution.

Table 1. The Sample distribution

\begin{tabular}{|c|c|c|c|c|}
\hline Region & Governorate & Member of governorate council & $\begin{array}{c}\text { Member of municipality } \\
\text { council }\end{array}$ & Opinion Leaders \\
\hline \multirow{2}{*}{ Meddle } & Amman & 53 & 75 & 28 \\
\cline { 2 - 5 } & Al-Balqa & 23 & 72 & 10 \\
\hline North & Irbid & 41 & 81 & 19 \\
\hline South & Al-Karak & 24 & 370 & 10 \\
\hline Total & $\mathbf{5 7 8}$ & 141 & 67 \\
\hline
\end{tabular}

Source: prepared by the Authors.

Two forms of the questionnaire were designed, the first to assess the decentralization experience at the governorate level and the second to evaluate the decentralization experience at the municipality level.

Each questionnaire includes two sections. The first relates to the social characteristics of the respondents (gender, age, qualification, years of experience and job title).

The second contains 24 questions to assess the political, administrative and financial decentralization at the governorate level. The other contains 28 questions to assess political, administrative and financial decentralization at the municipal level.

The five-point Likert scale was used to evaluate the study questions, as follows:

\begin{tabular}{|l|l|l|l|l|}
\hline I never agree & I don't agree & neutral & I agree & I totally agree \\
\hline 1 & 2 & 3 & 4 & 5 \\
\hline
\end{tabular}


The researcher used this scale to evaluate the extent of decentralization experience in Jordan: $(1-<2.33)$ low, $(2.33$ - < 3.66) moderate, and $(3.66-5)$ high. The mean and standard deviation were calculated for each question and a t-test was used to test the study hypotheses.

\section{The Result}

\subsection{Governorate Level}

The data contained in Table No. 2 indicate that the degree of decentralization assessment at the governorate level was moderate. The arithmetic mean value was estimated at $(3.13,2.70$ and 3.1$)$ for the political, financial and administrative dimension, respectively. and standard deviation of $(1.18,1.08$, and 0.98$)$, respectively.

Table 2. Means and standard deviations of the extent of the implementation of decentralization in Jordan: Political, administrative, and fiscal indicators

\begin{tabular}{|c|c|c|c|c|}
\hline no & Decentration Dimension & Mean & Standard Deviation & Extent \\
\hline 1 & Political & 3.13 & 1.18 & Neutral \\
\hline 2 & Administrative & 2.7 & 1.08 & Neutral \\
\hline 3 & Financial & 3.1 & 0.98 & Neutral \\
\hline
\end{tabular}

Source: prepared by the Authors.

\subsubsection{Political decentralization}

The mean values of the eight questions evaluating political decentralization ranged between 4.4 and 2.36), and the standard deviation value ranged between 0.69 and 1.436 . There is a strong belief among the respondents that the success of political decentralization depends on the availability of transparency and integrity in the elections of provincial council members. Citizens do not trust the central government to achieve these conditions. This explains the low rate of citizen participation in the 2017 elections, as this percentage reached (32\%).

Among the other reasons that the respondents see as negatively affecting political decentralization are:

1. The central government intervenes by appointing $15 \%$ of the total number of provincial council members.

2. Determining the women's quota by the central government.

3. The lack of political will for a number of central leaders, which would ensure the success of the decentralization experience at the governorate level.

Table 3. Means, Standard deviation, and Extent of political decentralization

\begin{tabular}{|c|c|l|c|c|c|}
\hline no & Rank & \multicolumn{1}{|c|}{ The Question } & Mean & $\begin{array}{c}\text { Standard } \\
\text { Deviation }\end{array}$ & Extent \\
\hline 5 & 1 & $\begin{array}{l}\text { The success of decentralization depends on the extent of } \\
\text { transparency and integrity in the provincial council elections }\end{array}$ & 4.4 & 0.69 \\
\hline 6 & 2 & $\begin{array}{l}\text { The appointed members participate in choosing the head of the } \\
\text { provincial council }\end{array}$ & 3.38 & 1.216 & Moderate \\
\hline 2 & 3 & $\begin{array}{l}\text { The percentage allotted to elected members and the majority } \\
\text { (85\%) in the provincial council is considered appropriate and } \\
\text { guarantees the implementation of political decentralization }\end{array}$ & 3.27 & 1.193 & Moderate \\
\hline 3 & 4 & $\begin{array}{l}\text { The application of the women's quota provided for in the } \\
\text { decentralization law contributes to an appropriate representation } \\
\text { of the women sector in the provincial council }\end{array}$ & 3.14 & 1.265 & Moderate \\
\hline 8 & 5 & $\begin{array}{l}\text { I believe that the application of political decentralization has } \\
\text { contributed to increasing the participation of citizens in } \\
\text { formulating the development decision at the governorate level }\end{array}$ & 3.09 & 1.339 & Moderate \\
\hline 4 & 6 & $\begin{array}{l}\text { The provincial council represents all segments of society } \\
\text { decentralization successfully at the governorate level }\end{array}$ & 2.87 & 1.436 & Moderate \\
\hline 1 & 7 & $\begin{array}{l}\text { There is the necessary political will in Jordan to implement } \\
\text { Society organizations and professional unions }\end{array}$ & 2.54 & 1.119 & Moderate \\
\hline 7 & 8 & $\begin{array}{l}\text { Within the decentralization law 2015 an active role for civil } \\
\text { TOTAL }\end{array}$ & 2.35 & 1.137 & Moderate \\
\hline
\end{tabular}

Source: prepared by the Authors. 


\subsubsection{Fiscal decentralization}

The mean values of the five questions evaluating fiscal decentralization ranged between (4.38) and (1.73), and the standard deviation ranged between (0.619) and (1.205) (see Table 4).

Table 4 also shows that the respondents strongly believe in the necessity of obtaining sufficient self-financing sources for the governorate, similar to the municipalities, to ensure the financial independence stipulated in the decentralization law. But this law never mentioned what these financial sources are. They also do not believe in the fairness of the basis for distributing the capital expenditure ceilings of the central government among the provinces, and it does not grant the provinces financial independence. They also believe that the provincial councils do not participate with the central government in the distribution of capital spending amount among the governorates.

Table 4. Means, Standard deviation, and Extent of financial decentralization

\begin{tabular}{|c|c|c|c|c|c|}
\hline no & Rank & The Question & Mean & $\begin{array}{l}\text { Standard } \\
\text { Deviation }\end{array}$ & Extent \\
\hline 5 & 1 & $\begin{array}{l}\text { I feel that there is an urgent need to provide financial } \\
\text { resources to the governorates, like the municipalities }\end{array}$ & 4.38 & 0.619 & high \\
\hline 2 & 2 & $\begin{array}{l}\text { The mechanism for determining financial ceilings for } \\
\text { capital spending and distributing it to governorates } \\
\text { enhances their financial independence and ability to carry } \\
\text { out their tasks }\end{array}$ & 3.78 & 1.064 & high \\
\hline 3 & 3 & $\begin{array}{l}\text { The provincial councils participate with the central } \\
\text { government in determining the bases for distributing } \\
\text { investment spending among the provinces }\end{array}$ & 2.84 & 1.205 & Moderate \\
\hline 1 & 4 & $\begin{array}{l}\text { The Decentralization Law } 2015 \text { specified financial } \\
\text { resources for the governorate to ensure its financial } \\
\text { independence }\end{array}$ & 2.76 & 1.157 & Moderate \\
\hline 4 & 5 & $\begin{array}{l}\text { Feel the fairness of the standards adopted in the } \\
\text { distribution of financial ceilings between governorates by } \\
\text { the central government }\end{array}$ & 1.73 & 0.890 & Moderate \\
\hline & & TOTAL & 3.10 & 0.980 & Moderate \\
\hline
\end{tabular}

Source: prepared by the Authors.

\subsubsection{Administrative decentralization}

The mean values of the eleven questions evaluating fiscal decentralization ranged between (3.86) and (2.17), and the standard deviation ranged between (0.944) and (1.222) (see Table 5). The respondents believe that the central government strongly controls the decisions of the governorate councils through the Ministry of Interior, and that the implementation of tasks in the governorate is carried out by the branches of the service ministries.

They also believe that the decentralization law 2015 did not grant the governorate councils the guarantor powers to achieve their administrative independence. They also pointed out that the law did not guarantee that there would be no duplication of powers between the official institutions in the governorate, especially between the elected president of the provincial council and the appointed governor and the head of the executive council. The finding of our study is consistent with a number of local studies (Taamneh et al., 2019).

Table 5. Means, Standard deviation, and Extent of administrative decentralization

\begin{tabular}{|c|c|l|c|c|c|}
\hline No & Rank & \multicolumn{1}{|c|}{ The Question } & Mean & $\begin{array}{c}\text { Standard } \\
\text { Deviation }\end{array}$ & Extent \\
\hline 2 & 1 & $\begin{array}{l}\text { The central government controls the decisions and actions } \\
\text { of the provincial councils }\end{array}$ & 3.86 & 1.130 & High \\
\hline 1 & 2 & $\begin{array}{l}\text { There is harmony between the elected provincial council } \\
\text { members and members of the executive council }\end{array}$ & 3.04 & 1.222 & Moderate \\
\hline
\end{tabular}


Table 5 (cont.). Means, Standard deviation, and Extent of administrative decentralization

\begin{tabular}{|c|c|c|c|c|c|}
\hline No & Rank & The Question & Mean & $\begin{array}{c}\text { Standard } \\
\text { Deviation }\end{array}$ & Extent \\
\hline 9 & 3 & $\begin{array}{l}\text { The decentralization law clearly ensured that the disputes } \\
\text { between the two councils in the governorate were resolved }\end{array}$ & 3.04 & 1.004 & Moderate \\
\hline 8 & 4 & $\begin{array}{l}\text { The decentralization law clearly ensured the limitation of } \\
\text { duplication of powers between the elected provincial } \\
\text { council and the central government agencies operating in } \\
\text { the province }\end{array}$ & 2.75 & 1.078 & Moderate \\
\hline 7 & 5 & $\begin{array}{l}\text { The councils in the governorate have the technical and } \\
\text { administrative capabilities to carry out their tasks } \\
\text { stipulated in the decentralization law }\end{array}$ & 2.67 & 1.134 & Moderate \\
\hline 11 & 6 & $\begin{array}{l}\text { The supervisory role that the elected provincial council } \\
\text { plays over the municipalities does not conflict with the } \\
\text { council's oversight role over government agencies } \\
\text { operating in the province. }\end{array}$ & 2.63 & 1.084 & Moderate \\
\hline 3 & 7 & $\begin{array}{l}\text { The powers contained in the Decentralization Law are } \\
\text { sufficient to implement administrative decentralization at } \\
\text { the governorate level }\end{array}$ & 2.52 & 1.013 & Moderate \\
\hline 10 & 8 & $\begin{array}{l}\text { The decentralization law defines the oversight role of the } \\
\text { elected governorate council over the municipalities }\end{array}$ & 2.40 & 0.944 & Moderate \\
\hline 4 & 9 & $\begin{array}{l}\text { Decisions issued by the elected provincial council are } \\
\text { binding on the central government agencies operating in } \\
\text { the province }\end{array}$ & 2.38 & 1.137 & Moderate \\
\hline 5 & 10 & $\begin{array}{l}\text { The oversight role of the elected provincial council is very } \\
\text { effective }\end{array}$ & 2.21 & 1.092 & Moderate \\
\hline 6 & 11 & $\begin{array}{l}\text { The decentralization law grants the governor and the } \\
\text { directors of government departments operating in the } \\
\text { governorate more powers, so that they cannot return to } \\
\text { their relevant ministries to carry out their work. }\end{array}$ & 2.17 & 1.008 & Moderate \\
\hline \multicolumn{3}{|c|}{ TOTAL } & 2.70 & 1.084 & Moderate \\
\hline
\end{tabular}

Source: prepared by the Authors.

\subsubsection{Testing Hypotheses}

The main null hypothesis at the governorate level states the following:

H01: The decentralization experience in general at governorate level is characterized by a low degree of decentralization (0.05).

The three sub-hypotheses below guided the analysis in terms of political, administrative, and fiscal decentralization in Jordan

H01.1: The political decentralization experience at governorate level is characterized by a low degree of decentralization (0.05).

H01.2: The financial decentralization experience at governorate level is characterized by a low degree of decentralization (0.05).

H01.3: The administrative decentralization experience at governorate level is characterized by a low degree of decentralization (0.05).

Given the estimated values of $(\mathrm{T})$, and the level of significance contained in Table No. 6, all the null hypotheses mentioned above are accepted. In other words, the degree of decentralization is low, with its three dimensions together: political, financial and administrative. 
Table 6. Testing research hypothesis

\begin{tabular}{|c|c|c|c|c|c|}
\hline Variable & Mean & $\begin{array}{c}\text { Standard } \\
\text { Deviation }\end{array}$ & $\begin{array}{c}\text { T-Value } \\
\text { calculated }\end{array}$ & df & Sig. \\
\hline Decentralization at Governorate level & 2.92 & 0.638 & -1.265 & 267 & 0.00 \\
\hline Political decentralization & 3.13 & 0.731 & 1.858 & 267 & 0.00 \\
\hline Financial decentralization & 3.10 & 0.623 & 1.669 & 267 & 0.00 \\
\hline Administrative decentralization & 2.70 & 0.723 & -4.443 & 267 & 0.00 \\
\hline
\end{tabular}

Source: prepared by the Authors.

\section{$5.1 \quad$ Municipality Level}

The data contained in Table No. 7 indicate that the degree of decentralization assessment at the municipality level was moderate. The arithmetic mean value was estimated at $(2.62,2.98$ and 2.84$)$ for the political, financial and administrative dimension, respectively. and standard deviation of (1.120,1.026, and 1.037), respectively.

Table 7. Means and standard deviations of the extent of the implementation of decentralization in Jordan:

Political, administrative, and fiscal indicators

\begin{tabular}{|c|c|c|c|c|}
\hline & Decentration Dimension & Mean & Standard Deviation & Extent \\
\hline 1 & Political & 2.62 & 1.120 & Neutral \\
\hline 2 & Administrative & 2.98 & 1.026 & Neutral \\
\hline 3 & Financial & 2.84 & 1.037 & Neutral \\
\hline
\end{tabular}

Source: prepared by the Authors.

\subsubsection{Political decentralization}

The mean values of the eight questions evaluating political decentralization ranged between 4.33 and 2.12), and the standard deviation value ranged between 0.748 and 1.628 (see Table 8). The respondents strongly believe that the 2015 Municipalities Law guarantees political representation for all segments of society and professional organizations. But the success of political decentralization, in their opinion, depends on the extent to which transparency and integrity are taken in conducting local elections. This explained the low rate of citizen participation in the voting process in the 2017 elections. They believe, to a very low degree, that the appointment of an executive director of the municipality strengthened the oversight role of the elected municipal council.

Table 8. Means, Standard deviation, and Extent of political decentralization

\begin{tabular}{|c|c|l|c|c|c|}
\hline no & Rank & \multicolumn{1}{|c}{ The Question } & Mean & $\begin{array}{c}\text { Standard } \\
\text { Deviation }\end{array}$ & Extent \\
\hline 5 & 1 & $\begin{array}{l}\text { Within the Municipal Law 2015 an active role for civil } \\
\text { society organizations }\end{array}$ & 4.33 & 0.874 & high \\
\hline 1 & 2 & $\begin{array}{l}\text { The division of the municipality into local areas, each } \\
\text { headed by an elected local council, led to an increase in } \\
\text { political participation }\end{array}$ & 3.02 & 1.628 & moderate \\
\hline 4 & 3 & $\begin{array}{l}\text { The success of political decentralization depends on the } \\
\text { extent of transparency and fairness in municipal elections }\end{array}$ & 2.42 & 1.145 & 1.080 \\
\hline 3 & 4 & $\begin{array}{l}\text { The elected municipal council represents all segments of the } \\
\text { local community }\end{array}$ & 2.29 & 1.075 & low \\
\hline 6 & 5 & $\begin{array}{l}\text { The application of political decentralization has contributed } \\
\text { to increasing citizen participation in the formulation and } \\
\text { implementation of local development decisions }\end{array}$ & 2.26 & 1.102 & low \\
\hline 2 & 7 & $\begin{array}{l}\text { The application of the women's quota contributes to the } \\
\text { representation of all spectrums of the local community }\end{array}$ & 2.22 & low \\
\hline 7 & 8 & $\begin{array}{l}\text { The appointment of an executive director for each } \\
\text { municipality strengthened political decentralization and } \\
\text { activate the oversight role of the elected municipal council }\end{array}$ & 2.12 & 1.022 & low \\
\hline Total & & & 2.62 & 1.120 & moderate \\
\hline
\end{tabular}

Source: prepared by the Authors. 


\subsubsection{Fiscal decentralization}

The mean values of the eight questions evaluating fiscal decentralization ranged between 4.32 and 2.12), and the standard deviation value ranged between 0.748 and 1.628 (see Table 9). The respondents strongly emphasize the need for the central government to grant municipalities more self-financial resources that would enable them to achieve financial independence and enable them to better provide local public services to citizens. They moderately believe that the municipality has qualified human and technical capabilities that ensure the efficient and effective collection of the municipality's financial resources.

Table 9. Means, Standard deviation, and Extent of fiscal decentralization

\begin{tabular}{|c|c|c|c|c|c|}
\hline no & Rank & The Question & Mean & $\begin{array}{c}\text { Standard } \\
\text { Deviation }\end{array}$ & Extent \\
\hline 8 & 1 & $\begin{array}{l}\text { I think that one of the duties of the CEO is to prepare and } \\
\text { implement the municipal budget and prepare the final accounts }\end{array}$ & 4.32 & 0.767 & high \\
\hline 7 & 2 & $\begin{array}{l}\text { I think that one of the duties of the municipal council is to approve } \\
\text { the municipal budget and follow up its implementation }\end{array}$ & 4.25 & 0.847 & high \\
\hline 6 & 3 & $\begin{array}{l}\text { There is an urgent need to provide additional funding sources to } \\
\text { enable the municipality to carry out its functions efficiently and } \\
\text { effectively }\end{array}$ & 4.04 & 0.888 & high \\
\hline 6 & 4 & $\begin{array}{l}\text { I think that the financial independence of the municipality enhances } \\
\text { the Implementation of financial decentralization at the local level }\end{array}$ & 3.69 & 0.983 & high \\
\hline 4 & 5 & $\begin{array}{l}\text { Municipalities possess the technical and human capacities qualified } \\
\text { to collect the self-financial resources efficiently and effectively }\end{array}$ & 2.52 & 1.215 & moderate \\
\hline 5 & 6 & $\begin{array}{l}\text { The central government is obligated to implement the distribution } \\
\text { mechanism stipulated in the Municipalities Law in distributing the } \\
\text { money that the government collects on behalf of the municipalities }\end{array}$ & 2.46 & 1.071 & moderate \\
\hline 1 & 7 & $\begin{array}{l}\text { I believe that the municipalities' share of taxes and fees collected by } \\
\text { the state is sufficient to enhance the financial independence of the } \\
\text { municipalities }\end{array}$ & 2.37 & 1.37 & moderate \\
\hline 2 & 8 & $\begin{array}{l}\text { I think that there is fairness in distributing the money collected by } \\
\text { the central government in favor of the municipalities from taxes and } \\
\text { fees between the municipalities }\end{array}$ & 2.33 & 0.965 & moderate \\
\hline \multicolumn{3}{|r|}{ (200 - } & 2.98 & 1.026 & moderate \\
\hline
\end{tabular}

Source: prepared by the Authors.

\subsubsection{Administrative decentralization}

The mean values of the seven questions evaluating administrative decentralization ranged between 4.06 and 2.31), and the standard deviation value ranged between 0.837 and 1234 (see Table1 ). Respondents highly believe that the 2017 Municipalities Law has given local authorities more local tasks, and reduced duplication of powers. However, they moderately believe that the municipalities do not have the human, technical and qualified capabilities that would enhance administrative decentralization.

Table 10. Means, Standard deviation, and Extent of administrative decentralization

\begin{tabular}{|c|c|l|c|c|c|}
\hline no & Rank & \multicolumn{1}{|c|}{ The Question } & Mean & $\begin{array}{c}\text { Standard } \\
\text { Deviation }\end{array}$ & Extent \\
\hline 1 & 1 & $\begin{array}{l}\text { The amended Municipalities Law 2015 includes more powers for } \\
\text { the municipality }\end{array}$ & 4.06 & 0.837 & high \\
\hline 4 & 2 & $\begin{array}{l}\text { The amended Municipalities Law 2015 limited the duplication of } \\
\text { powers between the Municipal Council and the central } \\
\text { government agencies at the local level }\end{array}$ & 3.97 & 0.892 & high \\
\hline 5 & 3 & $\begin{array}{l}\text { The formulation of the powers in the amended law was clear and } \\
\text { free from duplication that enables the municipal council and the } \\
\text { municipality director to implement them without hindrances }\end{array}$ & 2.45 & moderate \\
\hline 7 & 4 & $\begin{array}{l}\text { I think that the experience of administrative decentralization at the } \\
\text { local level was successful }\end{array}$ & 2.37 & 1.234 & moderate \\
\hline
\end{tabular}


Table 10 (cont.). Means, Standard deviation, and Extent of administrative decentralization

\begin{tabular}{|c|c|l|c|c|c|}
\hline no & Rank & \multicolumn{1}{|c|}{ The Question } & Mean & $\begin{array}{c}\text { Standard } \\
\text { Deviation }\end{array}$ & Extent \\
\hline 6 & 5 & $\begin{array}{l}\text { Municipalities possess the technical and human capabilities that } \\
\text { are able to carry out the tasks of the municipality efficiently and } \\
\text { effectively }\end{array}$ & 2.36 & 1.116 & moderate \\
\hline 2 & 6 & $\begin{array}{l}\text { I think that the amended Municipalities Law 2015 gave the } \\
\text { municipalities more tasks which in turn promote more } \\
\text { administrative decentralization }\end{array}$ & 2.35 & 1.041 & moderate \\
\hline 3 & 7 & $\begin{array}{l}\text { There is a need to separate the oversight role of the council from } \\
\text { the executive role of the municipality director in order to promote } \\
\text { decentralization }\end{array}$ & 2.31 & 0.997 & moderate \\
\hline Total & & 2.84 & 1.037 & moderate \\
\hline
\end{tabular}

Source: prepared by the Authors.

\subsubsection{Testing Hypotheses}

The main null hypothesis at the municipality level states the following:

H01: The decentralization experience in general at municipality level is characterized by a low degree of decentralization (0.05).

The three sub-hypotheses below guided the analysis in terms of political, administrative, and fiscal decentralization in Jordan.

H01.1: The political decentralization experience at municipality level is characterized by a low degree of decentralization (0.05).

H01.2: The financial decentralization experience at municipality level is characterized by a low degree of decentralization (0.05).

H01.3: The administrative decentralization experience at municipality level is characterized by a low degree of decentralization (0.05).

Given the estimated values of (T), and the level of significance contained in Table No. 6, all the null hypotheses mentioned above are accepted. In other words, the degree of decentralization is low, with its three dimensions together: political, financial and administrative.

Table 6. Testing research hypothesis

\begin{tabular}{|l|c|c|c|c|c|}
\hline \multicolumn{1}{|c|}{ Variable } & Mean & $\begin{array}{c}\text { Standard } \\
\text { Deviation }\end{array}$ & $\begin{array}{c}\text { T-Value } \\
\text { calculated }\end{array}$ & df & Sig. \\
\hline Decentralization at municipality level & 2.84 & 0.588 & -3.319 & 267 & 0.00 \\
\hline Political decentralization & 2.62 & 0.710 & -6.650 & 267 & 0.00 \\
\hline Financial decentralization & 2.98 & 0.585 & -0.372 & 267 & 0.00 \\
\hline Administrative decentralization & $\mathbf{2 . 9 2}$ & $\mathbf{0 . 6 0 9}$ & $\mathbf{- 1 . 7 0 3}$ & $\mathbf{2 6 7}$ & $\mathbf{0 . 0 0}$ \\
\hline
\end{tabular}

Source: prepared by the Authors.

\section{Conclusion and Recommendation}

This study concluded that the respondents evaluated the Jordanian decentralization experience at the two levels (governorates and municipalities) as moderate. This moderate evaluation (from their point of view as well) applies to all three dimensions of decentralization (political, financial and administrative). The statistical tests used in the study showed the acceptance of all the main hypotheses of the study, which confirm that the degree of decentralization in general at the level of the governorate and municipalities is low. The result does not differ for the sub-hypotheses of the following dimensions: political, financial and administrative. (estimated low). 
The study found the respondents' lack of conviction and confidence in the integrity and transparency of the local electoral process that took place in 2017. This was reflected in the low participation in those elections, as it was estimated at (31\%) according to the official reports of the Jordanian government.

The respondents believed that the decentralization law did not guarantee the financial independence of the provincial council, despite its affirmation of that. This is because financial resources (such as taxes and fees) are not the respondents believe that the provincial councils are unable to influence the determination and distribution of financial ceilings for the capital expenditure of the central government among the provinces. As well as the spending mechanism, which is the responsibility of the branches of ministries operating in the governorates. They also believe in the unfair distribution of public capital spending among the governorates. allocated to the governorate or shared with the central government.

From an administrative point of view, the respondents believe that the central government does not grant the agencies in the governorates powers to enable them to carry out their duties without consulting and waiting for the approval of the central authorities.

The lack of qualified human cadres, financial and technical resources in the governorates and in the municipalities weakens their ability to carry out their duties towards citizens and to implement decentralization successfully.

The respondents believed that the amended Municipalities Law 2015 granted municipalities additional powers and reduced duplication of powers. Assign the executive tasks in the municipality to the municipality manager instead of the mayor and the municipal councilj

The researchers recommend the following:

- Demanding the amendment of the Municipalities Law and the Decentralization Law by the central government, with the need to consider the results of studies conducted in the past period and to involve opinion leaders in regional and local communities in the expected amendment.

Recommending the need for the central government to delegate more powers to the governorate's organs, especially that the decisions of the elected governorate council become executive rather than advisory.

- Recommending the necessity of directly electing all members of the provincial council, similar to the House of Representatives at the national level and municipal councils at the municipal level.

We recommend the necessity of ensuring the financial independence of the governorates, like the municipalities, by allocating the proceeds of some taxes and fees from one side to them and sharing the proceeds of some of them, such as the oil derivatives tax, vehicle licensing fees, and violations.

We recommend that the central government should continue to prepare and implement plans, in cooperation with donor countries and agencies, to supply and rehabilitate human cadres and technical resources in order to enable them to carry out their planning and executive responsibilities in the political, financial and administrative fields efficiently and effectively. In a manner that ensures an increase in the degree of decentralization in order to achieve the royal directives, which King Abdullah II has consistently emphasized.

Funding: self-funded.

Author contribution: conceptualization, Aljaloudi, Jameel and Abu Zaid, Mohammad; data curation, Abu Zaid, Mohammad and Alfauri, Moath; formal analysis, Abu Zaid, Mohammad and Alfauri, Moath; funding acquisition, Aljaloudi, Jameel, Abu Zaid, Mohammad, Alfauri, Moath; investigation, Aljaloudi, Jameel, Abu Zaid, Mohammad, Alfauri, Moath; methodology, Abu Zaid, Mohammad and Alfauri, Moath; project administration, Aljaloudi, Jameel, Abu Zaid, Mohammad, Alfauri, Moath; Aljaloudi, Jameel; resources, Alfauri, Moath; software, Abu Zaid, Mohammad and Alfauri, Moath; supervision, Aljaloudi, Jameel; validation, Aljaloudi, Jameel; visualization, Alfauri, Moath; writing - original draft, Abu Zaid, Mohammad and Alfauri, Moath; writing - review \& editing Aljaloudi, Jameel. 


\section{References}

1. Abu Jabal Yazan (2020). The extent to which the administrative independence of the governorate councils in Jordan has been achieved in light of the method used in their formation. Journal of the Islamic University of Sharia and Legal Studies, 28(2). [Link].

2. Abu-Hazeem, Ghaith (2016). Decentralization and political reform in Jordan; the $17^{\text {th }}$ Parliament Memebrs point of view, Abo-Hazeem, Ghaith, Master Thesis, Middele East University Jordan. [Link].

3. Agrawal, A. and Ribot J. (1999). Accountability in Decentralization: A Framework with South Asian and West African Environmental Cases. The Journal of Developing Areas, 33, 473-502. [Link].

4. Al-Khwaldeh, Saleh (2019). Local Governance In Jordan: Governorate Councils Under The Law Of Decentralization No. (49) Of 2015: An Analytical Study”. In Journal of legal and political science, 9(3). [Link].

5. Aljaloudi, Jameel (2021). Fiscal decentralization in Jordan. In Journal of Governance and Regulation, 9(4). [Link].

6. Al Sarhan, Attallah (2020). Decentralization election in Jordan (2017). in Journal of Humanities and Social Sciences, 47(3). [GoogleScholar].

7. Al Tarawneh , Bashar (2020). Jordanian women's participation in elected local councils: A study of municipal and decentralization elections. In Journal of Humanities and Social Sciences, 47(3). [Link].

8. Crook, R. and Manor, J. (1998). Democracy and Descentralisation in South Asia and West Africa. Cambridge University Press, Cambridge. [Link].

9. Decentralization Law (2015). Ministry of Interior, Amman. Jordan. [Link].

10. Economic \& Social Council of Jordan (2019). Decentralization: Diagnosis and Suggested Scenario: ESCreport 2019. [Link].

11. Karak Castle Center for consultation and training in cooperation with Friedrich Ebert Stiftung (2018). Legal review of the Jordanian decentralization law. [Link].

12. Municipalities Law (2015). Ministry of Interior, Amman, Jordan. [Link].

13. Ribot, J. (2002). Democratic Decentralization of Natural Resources: Institutionalizing Popular Participation. World Resources Institute, Washington, DC. [GoogleScholar].

14. Schneider, A. (2003). Decentralization, conceptualization, and measurerment. Studio in Comparative International Development, 38(3), 35-55. [GoogleScholar].

15. Taamneh, M., Rawabdeh, M., and Abu-Hummour, A. (2019). Evaluation of decentralization experience through political, administrative, and fiscal: the case of Jordan”. In Journal of Public Affairs, 20(4). [Link].

16. The World Bank" Decentralization" (2013). [Link].

17. UNDP, Decentralized Governance Programme: Strengthening Capacity for People -Centered Development, Management Development and Governance Division, Bureau for Development Policy (September 1997). [Link]. 